\title{
Performance and carcass evaluation of balami rams finished on diets with varying energy level
}

${ }^{1}$ *Akinleye, S. B., ${ }^{1}$ Omojola, A. B., ${ }^{1}$ Offong ,U. A., ${ }^{2}$ Afolabi, K. D. and ${ }^{3}$ Luka, J. S.

${ }^{1}$ Department of Animal Science, Meat Science Laboratory, University of Ibadan, Ibadan,

Nigeria.

${ }^{2}$ Department of Animal Science,

University of Uyo, Uyo, Akwa Ibom State, Nigeria

${ }^{3}$ Department of Animal Science, University of Jos, Jos, Plateau State, Nigeria

Abstract *Corresponding E-mail: bamideleakinleye@yahoo.com

Fattening of farm animals is a way of increasing the rate of meat deposit after maturity. Its effectiveness depends on genetic status of the animal and the diet fed to the animal. In this study, performance and carcass evaluation of balami rams finished on diets with varying energy levels were carried. Forty-eight rams of Balami breed, weighing 20.75 \pm 1.50 $22.50 \pm 1.91 \mathrm{~kg}$ were randomly alloted to four dietary energy levels $(E L): 2.20 \mathrm{Mcal} / \mathrm{kg}\left(E L_{D}\right)$, $2.40 \mathrm{Mcal} / \mathrm{kg}\left(\left(E L_{I I}\right), 2.60 \mathrm{Mcal} / \mathrm{kg}\left(\left(E L_{I I}\right)\right.\right.$ and $2.80 \mathrm{Mcal} / \mathrm{kg}\left(\left(E L_{I V}\right)\right.$ for 90 days. The feed intake and daily weight gain of the animals in each treatment were determined and the average recorded. Three Balami rams were randomly selected from each treatment and sacrificed to determine the dressing percentage (DP), carcass weight $(C W)$, fat deposit $(F D)$ and meat yield (MY). Data were analysed using descriptive statistics and ANOVA at $\alpha_{0.05}$. The

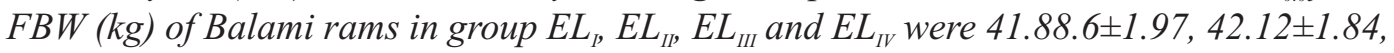
$46.13 \pm 1.65$ and $52.24 \pm 2.50$ while the FCR of animals on treatments $E L_{I}(5.3 \pm 0.28)$ and $E L_{I I}$ (5.2 \pm 0.26$)$ were higher than $E L_{I I I}(4.7 \pm 0.82)$ and $E L_{I V}(4.0 \pm 0.65)$. The DP (\%) were 54.9, 54.9, 55.8 and 56.1, the FD (\%) were 9.00,9.59,8.92 and 11.46 and the MY (\%) were 75.2, 74.7, 75.5 and 72.0 for rams on $E L_{I}, E L_{I I}, E L_{I I I}$ and $E L_{I V}$ The results indicate that, increasing levels of energy improved growth performance and carcass quality of Balami rams. Therefore, higher level of dietary energy (2.80 Mcal/kgDM and $14 \% \mathrm{CP}$ ) could be suggested for optimizing growth performance and meat quality of Balami ram under fattening condition.

Keywords: Balami, dietary energy, fattening, meat quality, dressing percentage, keeping quality

\section{Introduction}

Production of more rams and better quality meat are the most important elements of the intensive production systems, for instance, ram contributes to food production, rural employment and gross national product by converting roughages into meat, wool and skin (Abdel-Baset, 2009). However, under the traditional feeding systems without organized inputs, rams achieve $40-50 \mathrm{~g}$ of average daily gain in the most active phase of growth and are marketed for slaughter at 9-12 months of age weighing $20-22 \mathrm{~kg}$
(Karim, 2008). Rams need a high energy ration to assure high productivity and rapid growth (Manso et al., 2006). Higher levels of concentrate produce fatter carcasses than those rams reared on forages up to $\Delta$ nishing (Borton et al., 2005). Through intensive systems of management where rams are kept indoors and offered ad libitum concentrate and forage, productive performance of rams are improved compared to traditional systems (Mahgoub and Lodge, 1994). The principle of the intensive fattening process is concerned 
Performance and carcass evaluation of balami rams finished on diets with varying energy levels

with the use of intensive feed ingredients in order to benefit the high rate of development((Hosseini et al., 2008).

Energy is the major dietary element that is responsible for the different utilization of nutrients which in turn affect the productivity of the animal (Hosseini et al., 2008). The genetic potential of animals can be fully exploited only through accurate evaluation of their nutrient requirement and improved feeding management for growth performance (Mandal et al., 2005). Balami is one of the major breeds in Nigeria, essentially used for fattening programmes but their energy requirements have not been properly studied. Therefore, to optimize the improvement of Balami rams, emphasis on their energy requirements and their response to varying levels of energy rations needs to be evaluated.

\section{Materials and methods \\ Experimental animals and management}

Forty-eight Balami rams of about 12-14 months of age with initial live weight of $17.00 \pm 1.87-19.38 \pm 1.37 \mathrm{~kg}$ were used for this study. They were purchased at Akinyele Livestock Market and immediately transferred to the sheep and goat unit of the Teaching and Research Farm, University of Ibadan, where the study was carried out. After arrival, the animals were dewormed for internal parasites, sprayed for external parasites, vaccinated against some diseases predominant in the area and quarantined for 21 days.

After the adaptation period, the animals were neck tagged for identification and were randomly allotted to four dietary treatments $(2.20,2.40,2.60$ and $2.80 \mathrm{Mcal}$ digestible energy/kgDM) with similar levels of crude protein (14\%). The composition of the concentrate mix diets is as shown in Table 1. Panicum maximum hay was offered as basal diet and the experimental animals had access to the concentrate basal diets at the ratio of 60:40. The animals were fed at the rate of $5.0 \%$ of their respective body weight on daily basis. Concentrates feeding was twice daily (8:00 a.m. and 3:00 p.m.) while roughages was offered in-between the concentrate. Each animal had free access to water and salt-lick throughout the experiment. Live weight of rams was recorded once weekly, feed offered and refused daily was recorded in all groups. Feed conversion ratio was estimated based on the dry matter intake per $\mathrm{kg}$ of live weight gain. Feed intake was determined daily as the difference between feed offered and refusals. The feeding trials (fattening experiment) were carried out for 90 days.

\section{Slaughter procedure}

At the end of the feeding exercise, four animals were randomly selected from each of the dietary treatments and transported to the slaughter house of the Department of Animal Science, University of Ibadan. The animals were fasted for 16-hours with free access to water and weighed immediately prior to slaughter. A humane slaughter method was used, an incision was made on the jugular furrow at the occipito-atlantal junction close to the head, severing both the carotid arteries, jugular veins, trachea, oesophagus and the spinal cord. The head was removed, the carcass was skinned and eviscerated. The carcass components were weighed and recorded using an electronic scale (Cuisinart KML-K03BV36246China) and dressing percentage was calculated from the ratio of hot carcass weight to slaughter weight.

The carcass was then split along the mid line and the right half carcass was randomly selected and dissected into seven wholesale cuts according to AUS-MEAT (1998): hindleg, foreleg, neck, brisket, rack, loin and flank. Each cut was further dissected into components of lean meat, fat, bone and trimmings. The four components were 
52.24 while the average daily weight gain (ADWG) were $231.00 \mathrm{~g}, 237.50 \mathrm{~g}, 274.50 \mathrm{~g}$ and $325.00 \mathrm{~g}$ for rams on dietary energy levels of $\mathrm{EL}_{\mathrm{I}}, \mathrm{EL}_{\mathrm{II}}, \mathrm{EL}_{\mathrm{III}}$ and $\mathrm{EL}_{\mathrm{IV}}$ respectively. There were significant differences in the average daily weight gain of the animals from the different dietary energy levels $(P \leq 0.05)$. Increasing the energy level may allow the production of rumen microorganisms resulting in a rise in the synthesis of microbial protein and in the amount of protein available to the animal. The variation observed in the weight gain (g/day) of the rams could be attributed to the variation in the chemical constituents of the diets which seems to have an effect on the feed intake of the experimental animals. Ram growth rate, at a given age, is a function of feed intake rather than time
(Butterfeld, 1988). However, lower values were observed (up to $200 \mathrm{~g} /$ day) for tropical sheep fed with high-energy rations (Kawas et al., 2007). Feed conversion ratio is a trait of economic importance because it is this value that will show whether the animals were able to utilise the feed given to them effectively. From the results it was observed that animals on dietary $\mathrm{EL}_{\mathrm{IV}}$ had the best feed conversion ratio (4.04) followed by 4.70, 5.22 and 5.27 for animals on dietary $\mathrm{EL}_{\text {III, }}$ dietary $\mathrm{EL}_{\mathrm{II}}$ and $\mathrm{EL}_{\mathrm{I}}$, respectively. Higher values (between 8 and 12) were obtained by Mahgoub et al. (2005) with Omani lambs, whose ration consisted of $60 \%$ forage (Madhavi et al., 2006) with Nellore lambs fed neem seed cake based complete diets and Wildeus et al. (2007) with hair sheep fed $100 \%$ alfafa hay.

Table 3: Performance characteristics of fattened balami rams at different dietary energy levels

\begin{tabular}{|c|c|c|c|c|c|}
\hline & \multicolumn{5}{|c|}{ Treatments (Digestible Energy Mcal/kgDM) } \\
\hline & $1(2.2)$ & $\mathrm{II}(2.4)$ & III(2.6) & IV(2.8) & Pvalue \\
\hline Number of Ram & 12 & 12 & 12 & 12 & ------- \\
\hline Initial Live weight & $20.75 \pm 1.50$ & $20.50 \pm 1.00$ & $21.50 \pm 1.00$ & $22.50 \pm 1.91$ & 0.2342 \\
\hline Final Body Weight & $42.12 \pm 1.84^{\mathrm{c}}$ & $41.88 \pm 1.97^{\mathrm{c}}$ & $46.13 \pm 1.65^{\mathrm{b}}$ & $52.24 \pm 2.50^{\mathrm{a}}$ & 0.0001 \\
\hline Average Daily Weight Gain & $231.00 \pm 1.18^{\mathrm{c}}$ & $237.50 \pm 1.84^{\mathrm{c}}$ & $274.50 \pm 0.02^{b}$ & $325.00 \pm 0.01^{\mathrm{a}}$ & 0.0001 \\
\hline Daily Feed Intake/Head & $1.09 \pm 0.16^{\mathrm{a}}$ & $0.73 \pm 0.08^{b}$ & $0.78 \pm 0.09^{\mathrm{b}}$ & $0.81 \pm 0.02^{\mathrm{b}}$ & 0.0011 \\
\hline Daily Dry matter Intake/Head & $1.00 \pm 0.16^{\mathrm{a}}$ & $0.64 \pm 0.08^{b}$ & $0.68 \pm 0.08^{b}$ & $0.71 \pm 0.02^{\mathrm{b}}$ & 0.0010 \\
\hline Feed Conversion Ratio & $5.27 \pm 0.80^{\mathrm{b}}$ & $5.22 \pm 0.66^{\mathrm{ab}}$ & $4.70 \pm 0.48^{b}$ & $4.04 \pm 0.17^{\mathrm{a}}$ & 0.0001 \\
\hline Metabolic Body Weight ${ }^{(0.75)}$ & $16.53 \pm 0.54^{\mathrm{c}}$ & $16.46 \pm 0.58^{\mathrm{ab}}$ & $17.70 \pm 0.48^{\mathrm{b}}$ & $19.43 \pm 0.70^{\mathrm{a}}$ & 0.0478 \\
\hline
\end{tabular}

\section{Carcass characteristics and wholesale cuts}

Carcass characteristics of the animals showed that the the bled weight ranged from 92.01 to $95.18 \%$ while the empty body weight ranged from $61.19 \%$ to $64.20 \%$ (Table 4). Although there was no significant difference $(\mathrm{P}>0.05)$ between the values, but numerically, it was observed that the bled weight increased as the dietary energy increased. The hot carcass weight $(28.48 \mathrm{~kg})$ of animals on $\mathrm{EL}_{\mathrm{IV}}$ was significantly higher $(\mathrm{P}<0.05)$ than $24.67 \mathrm{~kg}$,
$22.91 \mathrm{~kg}$ and $23.17 \mathrm{~kg}$ for animals on $\mathrm{EL}_{\mathrm{II}}$ $\mathrm{EL}_{\text {II }}$ and $\mathrm{EL}_{\mathrm{I}}$ respectively. There were no significant differences $(\mathrm{P}>0.05)$ in the dressing percentage (DP) of the animals and it ranged from 54.90 to $56.08 \%$ and falls within the range $46-56 \%$ reported by Zimerman et al. (2008) in Creole kids. The values of some of the characteristics measured in this study are slightly higher than those reported by Momani Shaker et al. (1997) who reported an average slaughter weight of $42 . \mathrm{kg}$, average carcass weight of $21.96 \mathrm{~kg}$ and average dressing percentage 


\section{Akinleye, Omojola, Offong, Afolabi and Luka}

of $52.45 \mathrm{~kg}$ for pure Charollais rams reared in warm condition. The high DP obtained in this study indicated that there is a good profit margin for the farmer in the retail market.

Table 4: Carcass characteristics (relative to live weight) of Balami rams fattened at different dietary energy levels (Mcal/kgDM)

\begin{tabular}{lcccc}
\hline Parameters (kg) & I (2.2) & II (2.4) & III (2.6) & IV (2.8) \\
\hline Fasted body weight & $41.17 \pm 2.25^{\mathrm{bc}}$ & $40.33 \pm 2.47^{\mathrm{c}}$ & $44.50 \pm 1.80^{\mathrm{b}}$ & $50.83 \pm 2.25^{\mathrm{a}}$ \\
Bled weight & $93.29 \pm 0.45^{\mathrm{ab}}$ & $92.01 \pm 0.28^{\mathrm{b}}$ & $94.21 \pm 1.32^{\mathrm{a}}$ & $95.18 \pm 1.67^{\mathrm{a}}$ \\
Empty body weight & $61.73 \pm 3.05$ & $62.22 \pm 1.53$ & $61.19 \pm 1.88$ & $64.24 \pm 3.15$ \\
Chilled carcass weight & $95.63 \pm 0.38^{\mathrm{c}}$ & $96.72 \pm 1.15^{\mathrm{bc}}$ & $97.93 \pm 0.11^{\mathrm{b}}$ & $99.30 \pm 0.61^{\mathrm{a}}$ \\
Chilling loss (\%) & $4.37 \pm 0.38^{\mathrm{a}}$ & $4.11 \pm 0.45^{\mathrm{a}}$ & $2.07 \pm 0.11^{\mathrm{b}}$ & $0.58 \pm 0.52^{\mathrm{c}}$ \\
Hot carcass weight & $23.17 \pm 1.76^{\mathrm{b}}$ & $22.91 \pm 1.28^{\mathrm{b}}$ & $24.67 \pm 2.08^{\mathrm{b}}$ & $28.48 \pm 1.29^{\mathrm{a}}$ \\
Dressing percentage (\%) & $54.90 \pm 1.22$ & $54.92 \pm 0.39$ & $55.77 \pm 1.06$ & $56.08 \pm 1.52$ \\
\hline
\end{tabular}

${ }^{\mathrm{a}, \mathrm{b}, \mathrm{c}}$ :Means with different superscripts in the same row are significantly different $(\mathrm{P}<0.05)$.

\section{Distribution of tissues}

As growth continues, the ratio of bone to carcass weight decreases while muscle ratio increases, and thus the muscle to bone ratio increases with an increase in carcass weight. As maturity is reached, the percentage of muscle to carcass weight will start to decrease as the percentage of fat starts to increase (fattening phase) (Roy et al., 2005).

The tissue distribution values were meat (75.17, 74.67, 75.55 and $72.00 \%$ ), bone $(14.44,14.52,14.11$ and $14.91 \%)$ and fat
(9.00, 9.59, 8.92 and $11.86 \%)$ for Balami rams on $\mathrm{EL}_{\mathrm{I}}, \mathrm{EL}_{\mathrm{II}}, \mathrm{EL}_{\mathrm{III}}$ and $\mathrm{EL}_{\mathrm{IV}}$, respectively. The relatively close meat-tobone ratio of rams in this study indicated that there was uniform rate of meat and bone deposition in the experimental rams which support the report of Ewnetu et al. (2006) that observed significant differences in meat-to-bone ratio in Menz and Horro sheep. However, Krishna et al. (1983) reported no significant effect in the proportion of meat-to-bone ratio among lambs fed complete rations.

Table 5: Distribution of tissues of Balami rams carcass fed different dietary energy levels ( $\%$ hot carcass weight)

\begin{tabular}{lccccc}
\hline \multicolumn{7}{c}{ Treatments } & (Digestible Energy & Mcal/kgDM) & & \\
\hline Parameters (\%) & $1(2.2)$ & $2(2.400)$ & $3(2600)$ & $4(2800)$ & Pvalue \\
\hline Meat & $75.17 \pm 0.73^{\mathrm{a}}$ & $74.67 \pm 1.51^{\mathrm{a}}$ & $75.55 \pm 4.09^{\mathrm{a}}$ & $72.00 \pm 7.33^{\mathrm{b}}$ & 0.0164 \\
Bone & $14.44 \pm 0.23^{\mathrm{ab}}$ & $14.52 \pm 0.74^{\mathrm{ab}}$ & $14.11 \pm 2.68^{\mathrm{b}}$ & $14.91 .2 .24^{\mathrm{a}}$ & 0.0984 \\
Fat & $9.00 \pm 0.48^{\mathrm{b}}$ & $9.59 \pm 1.71^{\mathrm{b}}$ & $8.92 \pm 1.88^{\mathrm{b}}$ & $11.46 \pm 4.74^{\mathrm{a}}$ & 0.0009 \\
Losses & $1.25 \pm 0.21$ & $1.07 \pm 0.84$ & $1.16 \pm 0.62$ & $1.47 \pm 0.18$ & 0.4584 \\
Meat : Bone & $5.22 \pm 0.06^{\mathrm{a}}$ & $5.14 \pm 0.12^{\mathrm{ab}}$ & $5.32 \pm 0.55^{\mathrm{a}}$ & $4.84 \pm 0.52^{\mathrm{b}}$ & 0.0719 \\
Meat : Fat & $8.42 \pm 0.23^{\mathrm{a}}$ & $7.79 \pm 0.61^{\mathrm{a}}$ & $8.52 \pm 0.38^{\mathrm{a}}$ & $6.09 \pm 1.34^{\mathrm{b}}$ & 0.0037 \\
\hline
\end{tabular}

${ }^{a, b, c}:$ Means with different superscripts in the same row are significantly different $(p<0.05)$.

\section{Conclusion}

The results of the present study showed that high energy based diet has positive effects on fattening performance of rams. Balami rams have better feed conversion when a concentrate is used. It can be inferred from this study that fattening of Balami rams under feedlot system for a period of 90 days 
Performance and carcass evaluation of balami rams finished on diets with varying energy levels

with optimum dietary energy levels of 2.60 and $2.8 \mathrm{Mcal} / \mathrm{kg} \mathrm{DM} ; 14 \% \mathrm{CP}$ will give rise to animals with good growth performances, carcass and quality meat yield. The feed resources used in this study are locally available and their use will greatly increase meat production for the export and domestic market.

\section{References}

Abdel-Baset, N. S. 2009. Effect of Different Dietary Energy Levels on the Performance and Nutrient Digestibility of Lambs, Veterinary World, Vol.2(11):418-420

AOAC 1990. Official Methods of Analysis, 18 th Edition. Association of Official Analytical Chemists, Washington, DC.

AUS-MEAT 1998. Handbook of Australian Meat. 6th edition (AUS-MEAT: Brisbane). www.ausmeat.com

Bellof, G. and Pallauf, J. 2004. Deposition of protein, fat and energy in lambs of the a. Breed German Merino Land sheep. Animal. Science. 78(3): 369-378

Butterfeld, R. M. 1988. New Concepts in Sheep Growth. University of Sydney, Australia, 168 pp.

Dinius, D. A. and Baumgardt, B. R. 1969. Regulation of food intake in ruminants. 6. Influence of caloric density of pelleted rations. J. Dairy Sci. 53, $311 \pm 316$.

Ewnetu, E., Alemu, Y. and Rege, J. E. O. 2006. Slaughter character- istics of Menz and Horro sheep. Small Ruminant Research, 64, 10-15.

Gallo, C., leBreton, Y., Wainnright, I., and Berkhoff, 1996. Body and carcass composition of amale and female criollo goats in the South of Chile. Small Ruminant Research 23: 163-169
Haddad, S. G., Nasr, R. E. and Muwalla, M. M 2001. Optimum dietary crude protein level for finishing Awassi Lamb. Small Ruminant Research, 39(1): 41-46.

Hosseini, S. M. 2008. Effect of different energy levels of diet on feed efficiency, growth rate and carcass characteristics of fattening lambs. Journal Animal. \& Vetenary Advances, 7(12): 1551-1554

Kawas, J. R., García-Castillo, R., Fimbres-Durazo, H., GarzaCazares, F., Hernández-Vidal, J. F. G., Olivares-Sáenz, E. and Lu, C. D. 2007. Effects of sodium bicarbonate and yeast on nutrient intake, digestibility, and ruminal fermentation of light-weight lambs fed finishing diets. Small Ruminant Research 67:149-156.

Krishna-Mohan, D. V. G. and Charyulu, E. K. 1983. Studies on growth, nutrient utilization and carcass characteristics in lambs fed rations having different proportions of concentrate to roughage. Indian Journal of Animal Sciences 53, 1228-1233.

Lawrie, R.A. and Ledward, D.A 2006. Lawrie's Meat Science. (7th ed.). Woodhead Publ. Ltd., Cambridge. England. pp. 15-40.

Madhavi, K., Reddy, Y., Reddy, Y. R. and Reddy, G. V. N. 2006. Effect of feeding differently processed detoxified neem (Azadirachta indica) seed cake based complete diets on growth, nutrient utilization and carcass characteristics in Nellore sheep, Livestock Research for Rural Development 18 (10), h t t p : / / w w w . 1 r r d . org / lrrd18/10/madh18140.htm

Madruga, M. S., Torres, T. S., Carvalho, F. F., Queiroga, R. C., Narain, N., 
Garrutti, D., Souza, A. N. M., Mattos, C. W. and Costa, R. G. 2008. Meat quality of Moxotó and Canindé goats as affected by two levels of feeding. Meat Science. 80:1019-1023.

Mahgoub, O., Lu, C. D., Hameed, M. S., Rcichie, A., Al-Halhali, A. S. and Annanamalai, K. 2005. Performance of Omani goats fed diets containing various metabolizable energy densities. Small Ruminant Research. 58:175180

Mandal, A. B., Paul, S. S., Mandal, G. P., Kannan, A. and Pathak, N. N. 2005. Deriving nutrient requirements of growing Indian goats under tropical condition. Small Ruminant. Research. 58: 201-217.

Momani Shaker, M., Šáda, I., Vohradský, F. 1997. Analysis of parameters of fattening ability and carcass value of ram lambs of the Charollais breed. Scientia Agric. Bohemica, 28:39-49.

NABARD, 2007. Lamb fattening-Model Bankable Projects (Annexure V)

SAS, 1999. SAS user's guide. Statistical Analysis System, SAS Institute Inc., Cary.

Roy, T. B. and Rex, M. B. 2005. New concepts of cattle growth. The Internet-first University press. International book distributors limited. Hemel Heempstead, $\begin{array}{lllllllll} & \mathrm{n} & \mathrm{g} & \mathrm{l} & \mathrm{a} & \mathrm{n} & \mathrm{d} & \text {. }\end{array}$ $\mathrm{http} / / \mathrm{dspace}$.library.cornell. edu/handle/1813/62
Sendros, D. and Tesfaye, K. 1998. Factors to be considered in the formulation of livestock breeding policy. In: Proceedings of The Fifth National Conference of Ethiopian Society of Animal Production (ESAP), Addis Ababa. ESAP. pp: 13-27

Shadnoush, G. H., Ghorbani, G. R. and Edris, M. A. 2004. Effect of different energy Levels in feed and slaughter weights on carcass and chemical composition of LoriBakhtiari ram lambs. Small Ruminant Research 51: 243-249

Wildeus, S., Turner, K. E. and Collins, J. R. 2007. Growth, intake, diet digestibility and nitrogen use in three hair sheep breeds fed alfalfa hay. Small Ruminant Research 69: 221-227

Van Soest, P. J., Robertson, J. B. and Lewis, B. A. 1991. Methods for dietary fiber, neutral

detergent fibre and nonstarch polysaccharides in relation to animal nutrition. J. Dairy Sci. 74: 3583-3597.

Zimerman, M., Domingo, E. and Lanari, M. R. 2008. Carcass characteristics of Nenquen criollo kids in Patagonia region, Argentina. Meat Science 79: 453457.

Received: $25^{\text {th }}$ August, 2016 Accepted: 12 $2^{\text {th }}$ March, 2017 